\title{
Assessment of Building Vulnerability to Tsunami Hazard in Kamari (Santorini Island, Greece)
}

\author{
Dimitrios-Vasileios Batzakis ${ }^{1, *}$, Loukas-Moysis Misthos ${ }^{2} \mathbb{D}$, Gerasimos Voulgaris ${ }^{3}$, \\ Konstantinos Tsanakas ${ }^{1}$ (D), Maria Andreou ${ }^{1}$, Ioannis Tsodoulos ${ }^{1}$ and Efthimios Karymbalis ${ }^{1}$ (D) \\ 1 Department of Geography, Harokopio University, 70 El. Venizelou Str., 17671 Athens, Greece; \\ ktsanakas@hua.gr (K.T.); mandreou@hua.gr (M.A.); ioannis.tsodoulos@gmail.com (I.T.); \\ karymbalis@hua.gr (E.K.) \\ 2 School of Mining and Metallurgical Engineering, National Technical University of Athens, 9 Iroon \\ Polytechniou Str., Zografou Campus, 15772 Zografou, Greece; mosesmisthos@yahoo.com \\ 3 Faculty of Foreign Studies, Reitaku University, 2-1-1 Hikarigaoka, Kashiwa 277-8686, Japan; \\ gvsquall@gmail.com \\ * Correspondence: mpatzakis@hua.gr
}

Received: 19 September 2020; Accepted: 5 November 2020; Published: 7 November 2020

\begin{abstract}
Santorini Island, located in the Southern Aegean Sea, is prone to tsunamis due to its proximity to the Hellenic subduction zone, which is one of the major tsunamigenic areas. Characteristic events, such as those of 365 A.D. and 1303 A.D. greatly affected the coasts of the Eastern Mediterranean Sea, causing significant loss of life and construction damage. Tsunami disaster risk is nowadays significantly higher due to the increased exposure of the buildings as a result of the economic and touristic growth of the Aegean Islands. This study focuses on the eastern coast of Santorini, since its morphology and human presence amplify the necessity to assess its building vulnerability. After conducting an exposure analysis at the settlements of the eastern coast, Kamari poses the highest physical, social and economic relative exposure to any potential natural hazard. The main objective of this research is to quantify the building stock's vulnerability to tsunami hazard. For this purpose, a "worst-case run-up scenario" was developed. Considering the history of tsunamis in the Aegean Sea, an extreme sea-level rise after a $10 \mathrm{~m}$ a.s.l. tsunami run-up, caused by an earthquake with $\mathrm{M}_{\mathrm{w}} \sim 8.5$, was assumed. The relative vulnerability of the buildings in Kamari was calculated via the application of the Papathoma Tsunami Vulnerability Assessment (PTVA-4) analytic model. The results indicate that 423 buildings are within the inundation zone, $58 \%$ of which are characterized as highly and very highly vulnerable to tsunamis, revealing the problematic characteristics of the building stock, offering important information to the decision-makers to mitigate a possible future tsunami impact.
\end{abstract}

Keywords: tsunami hazard; exposure; building vulnerability; PTVA-4; Southern Aegean Sea; Santorini; Kamari

\section{Introduction}

Tsunamis are extreme waves that are triggered by other natural hazards, such as earthquakes, submarine or coastal landslides and volcanic activity. These hazards are capable of causing a severe disturbance in the water mass, providing it with high energy, resulting in enormous waves [1-3]. However, the main cause of tsunamis worldwide is earthquakes. Their intensity is directly related to the characteristics of the earthquake, such as the magnitude, the focal depth, and the length and direction of the surface rupture of the activated fault. The larger tsunamis are associated with the subduction zones' geodynamic process along convergent plate boundaries [4]. The main wave characteristics of tsunamis are similar to those of wind-generated waves, but the speed at which they can travel is 
extremely high, reaching up to hundreds of $\mathrm{km} / \mathrm{h}[5,6]$. Tsunamis have the ability to maintain their kinetic energy over long distances, enabling them to spread in any direction and potentially to affect any coastal area. Moreover, the incipient breaking wave height is significantly greater than the usual waves and can reach, in extreme cases, tens of meters [6].

Two main characteristics of a tsunami wave, describing its risk potential, are the run-up and the inundation zone. The run-up expresses the maximum vertical distance between the mean sea-level and the highest point to which the flood zone extends inland and indicates a short-term sea-level rise caused by a tsunami. In other words, run-up represents the maximum elevation at which the inundation flows can reach. Inundation zone is defined as the maximum horizontal intrusion of the flood flows in the coastal area [7]. Both of these characteristics are positively correlated with the magnitude of the earthquake and express the intensity of the tsunami [6]. Along with the aforementioned characteristics, flow depth and flow velocity are critical factors impacting the potential building damage [8].

Proximity to a tectonic plate boundary, particularly in subduction zones, as well as to submarine active major fault zones, characterizes the coastal areas as prone to tsunamis, and increases the risk [9]. The aftermath of the two recent and extreme events of 2004 and 2011 in the Indian Ocean and Japan, respectively, revealed that both developing and developed societies are vulnerable to tsunamis. The knowledge of past events is crucial in revealing the proneness to this particular hazard. The identification of such events is often achieved through archaeological and historical evidence. Direct or indirect indications may come from references to historical texts, while structural indications are derived from the studies of ruins of ancient structures [10-12]. In addition, in recent decades, significant efforts have been made to identify events through the study of coastal geomorphology, as well as coastal and submarine stratigraphy [13-15]. Tsunami waves are associated with corrosive and depositional processes [16-18] and usually lead to the deposition of a characteristic sedimentary unit in the stratigraphic column of coastal low-energy environments which is called "tsunamite" [19]. Additionally, deep-sea sedimentary deposits located at the bottom of the Mediterranean Sea, which are linked with the action of tsunami waves, are called "homogenites" [2,20].

Throughout the Mediterranean basin, a plethora of geographical areas can be identified with features capable of creating tsunamis. Greece is one among the countries most prone to tsunamis, due to its location within the broader geodynamic setting of the Eastern Mediterranean Sea. The main mechanisms that create tsunamis are considered to be either the surface deformation of the seabed by the activation of a fault, or the triggering of a submarine landslide after an earthquake or volcanic activity [21]. The tsunamigenic zones in Greece with the highest potential are the eastern and western parts of the Hellenic Arc, the fault zones within the Aegean Sea and the Gulf of Corinth [22-24].

Although the historical records include dozens of such high energy marine events in the Aegean Sea, the hazard, until recently, was underestimated. Since antiquity until the present, many catastrophic tsunamis have affected coastal areas in Greek mainland and islands. Tsunami catalogues provide important information about these past events, such as the generation mechanism, the date of occurrence, the area of origin and the areas the tsunamis affected [21,25]. However, there is not enough information in the literature about the consequences of these tsunami events, particularly the events that occurred in the past few centuries. According to Bryant (2014) [6], 30\% of the earthquakes in Greece cause tsunamis with measurable characteristics, while about 20 major events have been identified [7]. Characteristic extreme tsunami wave events, such as the 365 A.D. and 1303 A.D. ones, which followed the two earthquakes with magnitudes of $\mathrm{M}_{\mathrm{w}}=8.3$ and $\mathrm{M}_{\mathrm{w}}=8.0$, respectively, and with an estimated 9 $m$ a.s.l. run-up, greatly affected the coasts of the Eastern Mediterranean Sea [7,21,26-30].

Aside from earthquake-originated sea waves, tsunamis caused by submarine landslides, triggered mainly by seismic events, can also affect the Aegean Sea coasts, producing extensive run-up. For instance, the 1956 A.D. Amorgos tsunami, triggered by a magnitude of $\mathrm{M}_{\mathrm{w}}=7.4$ seismic event, impacted several islands of the Cyclades complex, recording a run-up of at least $10 \mathrm{~m}$ a.s.l. [5,31-33]. Moreover, volcanic activity was the cause of one of the largest tsunamis in the Mediterranean Sea that initiated the decline of Minoan Civilization in the Late Bronze Age [14,34]. Similarly, a tsunami with a 
run-up exceeding $2 \mathrm{~m}$ a.s.l. and a sea-water inundation over $3 \mathrm{~km}$ inland, caused by the collapse of the Columbo submarine volcanic cone, NE of Santorini, was recorded in 1650 A.D., affecting many islands of the Cyclades complex as well [35].

The aforementioned events have caused significant loss of life and construction damage in the past. There is a high likelihood for similar events to take place and affect the coasts of the Aegean Sea in the near future. Furthermore, the disaster risk is now significantly higher due to the increased exposure of the buildings, as a result of the economic and touristic growth of the Aegean Islands. The need to consolidate the safety of coastal human societies against tsunamis, necessitates the assessment of different aspects of vulnerability. The objective of this study focuses on the assessment of the building stock vulnerability to tsunamis for the coastal settlement of Kamari, Santorini, by applying the Papathoma Tsunami Vulnerability Assessment (PTVA-4) model [36]. Vulnerability expresses the susceptibility of an entity in consequences, such as casualties, damage, destruction or general losses due to the occurrence of a hazard [37]. In this paper, vulnerability refers to the physical type of vulnerability that concerns damage in the buildings. In order to quantify the building stock's vulnerability, a "worst-case run-up scenario" was developed, which was derived from scientific research that links tsunami run-up to earthquake magnitude [38] based on the history of tsunami characteristics in the Southern Aegean Sea [21]. Therefore, the aim of this study is to analyze the building vulnerability to tsunamis, providing decision-makers with useful information on the potential impact of a future tsunami event. Building vulnerability assessment can be an important part of the mitigation strategy. Furthermore, as a systematic approach, it aids in reducing the effects of an upcoming disaster and helps in reshaping public policies and plans by improving building codes, building use regulations and land use management.

\section{Study Area}

Santorini is a volcanic island located in the Southern Aegean Sea, approximately $150 \mathrm{~km}$ north of the active convergent Africa-Eurasia plate boundary. Hence, the region is dominated by geodynamic processes related to the subduction of the northern part of the African tectonic plate beneath the Aegean microplate at a rate of $\sim 3.5-4.0 \mathrm{~cm} /$ year $[39,40]$. Santorini is situated in the middle of the inner volcanic arc, and is the most active volcanic center, with nine eruptions in the last six centuries [41]. The recent island complex of Santorini is the remnants of the prehistoric Strongyli, an island created by volcanic activity during the Plio-Quaternary. The ancient name Strongyli is derived from the circular shape of the island [42]. Santorini consists of a metamorphic bedrock and various types of volcanic rocks. The main geomorphic feature of the island is the steep caldera formed during the eruption of the volcano in the Late Bronze Age, around 3500 years B.P. [43,44].

The seismicity in the wider area is controlled by extensional faulting within the Aegean microplate (Figure 1). The most typical tectonic feature is the Santorini-Amorgos fault zone where the largest tsunamigenic earthquake of the last century was recorded in 1956. The earthquake had a magnitude of $\mathrm{Mw}=7.4$ followed by an aftershock of $\mathrm{Mw}=7.2[11,29]$. However, the most seismically active area is the Hellenic subduction zone, where earthquake magnitudes could reach a maximum of $\mathrm{Mw}=8.5$, and where the largest tsunamis were generated, affecting the coasts of the entire Mediterranean basin (such as the events of 365 and 1303 A.D.) [28,45].

This study focuses on the coastal settlement of Kamari at the eastern coast of Santorini. The coastal geomorphology of the area along with the intense human activities amplify the necessity of its vulnerability assessment. In terms of disaster management, Kamari poses the highest physical, social and economic relative exposure to natural hazards. According to the Hellenic Statistical Authority (2014) [46], Kamari has the highest population density (433 residents $/ \mathrm{km}^{2}$ ) hosting 10\% (1344 residents) of the total island's population. The number of buildings in Kamari amounts to 849 . The majority are used as dwellings (55\%), tourist facilities (21\%) and commercial stores (15\%) [47]. Kamari is ranked among the most touristically developed settlements of the island. It is a "mass tourism" holiday destination and can accommodate more than 8000 visitors. This means that the seasonal population of 
the summer months can potentially reach 9500 people and the corresponding population density can exceed 3000 people $/ \mathrm{km}^{2}$. Furthermore, the presence of critical facilities, including medical centers, schools and the airport raises the risk. With a coastline length of $2 \mathrm{~km}$ and maximum elevation of $50 \mathrm{~m}$, the number of the buildings vulnerable to tsunami is increased.

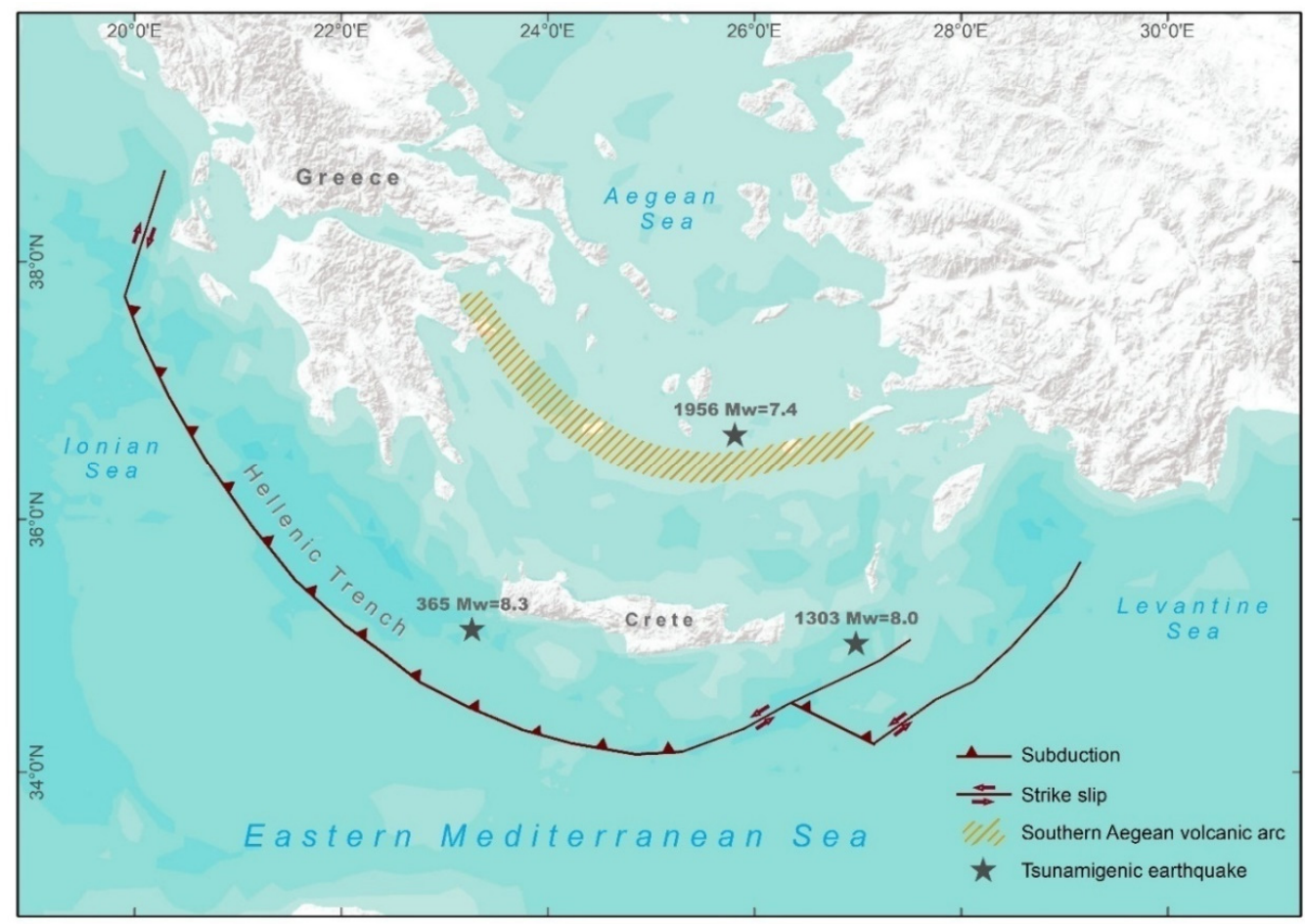

Figure 1. Simplified map of the geotectonic setting of the Eastern Mediterranean Sea (after [25]). The epicenters of some of the major tsunamigenic earthquakes in the Southern Aegean Sea are also depicted (after [18]).

\section{Materials and Methods}

\subsection{Coastal Settlements Exposure Analysis}

In an attempt to determine which coastal settlement of the island the methodology would be applied to, an investigation of the exposure to any potential natural hazard at the settlement-level took place, since detailed data for the coastal zone were not available. Exposure is an important component in developing strategies for risk reduction management. It is defined as the number of all the synthetic elements of a society, including people, infrastructure, dwellings, critical facilities and production capacities, which are located in a hazard-prone area [48]. An analysis was carried out to quantify the exposure by examining the multi-level structures and functions that compose the settlements as an entity exposed to natural hazards. According to this analysis, the total exposure is expressed as the sum of the critical variables that potentially add to the vulnerability. In the context of the exposure assessment of the coastal settlements in Santorini, total exposure is expressed as follows:

Total Exposure $=$ Social Exposure + Physical Exposure + Economic Exposure

To calculate the total exposure, 15 variables were taken into account, and were categorized into three main groups and six subgroups (Figure 2). The categorization of variables was based on the type of exposure and its resulting vulnerability (social, physical and economic). Social exposure includes variables related to the population characteristics, such as the population density and the vulnerable population; physical exposure includes the building stock and the critical facilities; economic exposure includes the buildings related to economic development and the main residences (see $[49,50]$ ). 


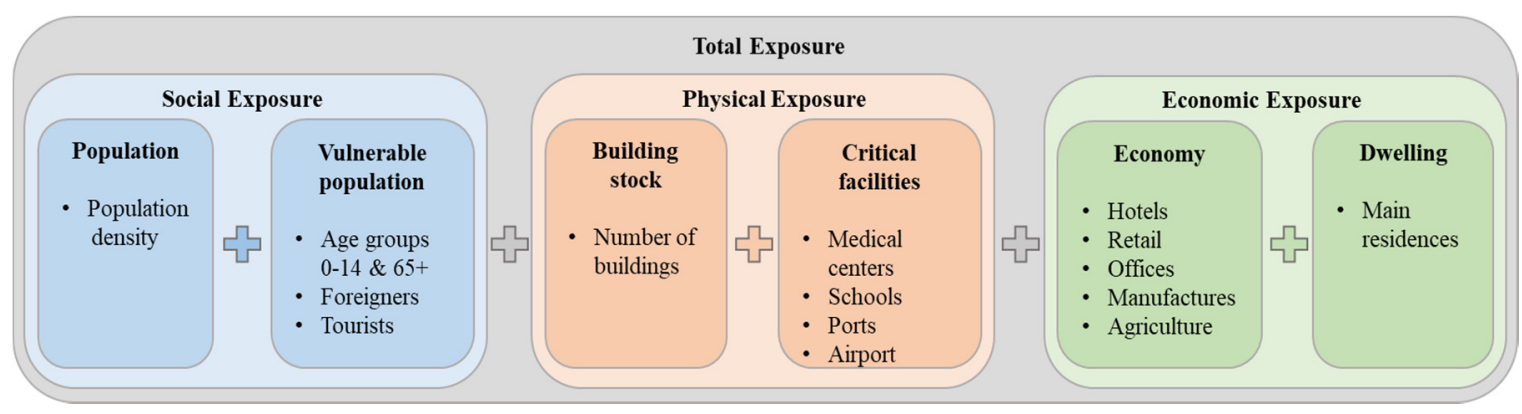

Figure 2. Total Exposure calculation framework.

The necessary information was obtained from the "2011 Population-Housing Census" [46]. The data were organized in a database according to the population of each variable. The individual subgroups were classified using the "Natural Breaks (Jenks)" classification method. Since Santorini is a tourist destination, both the winter and the summer exposure were estimated. The seasonal variation in the total exposure, is a result of the variation in the social exposure, which is dependent on the number of tourists that visit the settlements. The tourists affect the population density of each settlement, resulting in an increase in the population during the summer months. Moreover, the tourists were counted as a vulnerable group, due to difficulties in understanding the local language. The fact that they are in an unknown environment, and that they might face a natural hazard that is unknown to them, adds more to their vulnerability [51]. The analysis of the seasonal exposure indicates that Kamari appears to be the settlement with the highest exposure in natural hazards, in both winter and summer (Figure 3). According to the results of this analysis, the building vulnerability assessment method focused on the coastal settlement of Kamari.

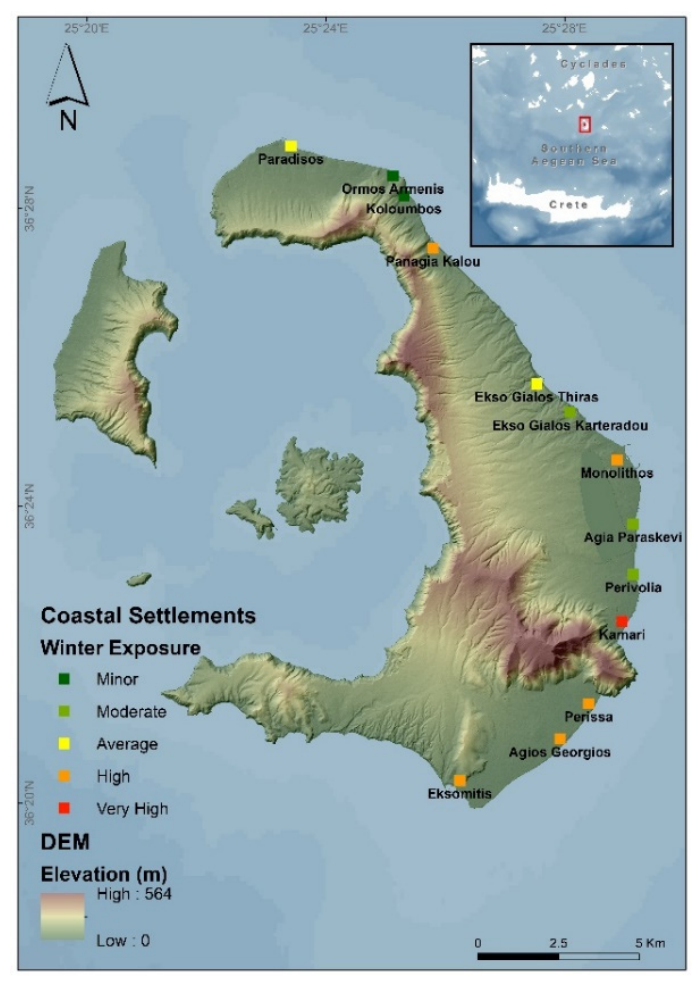

(a)

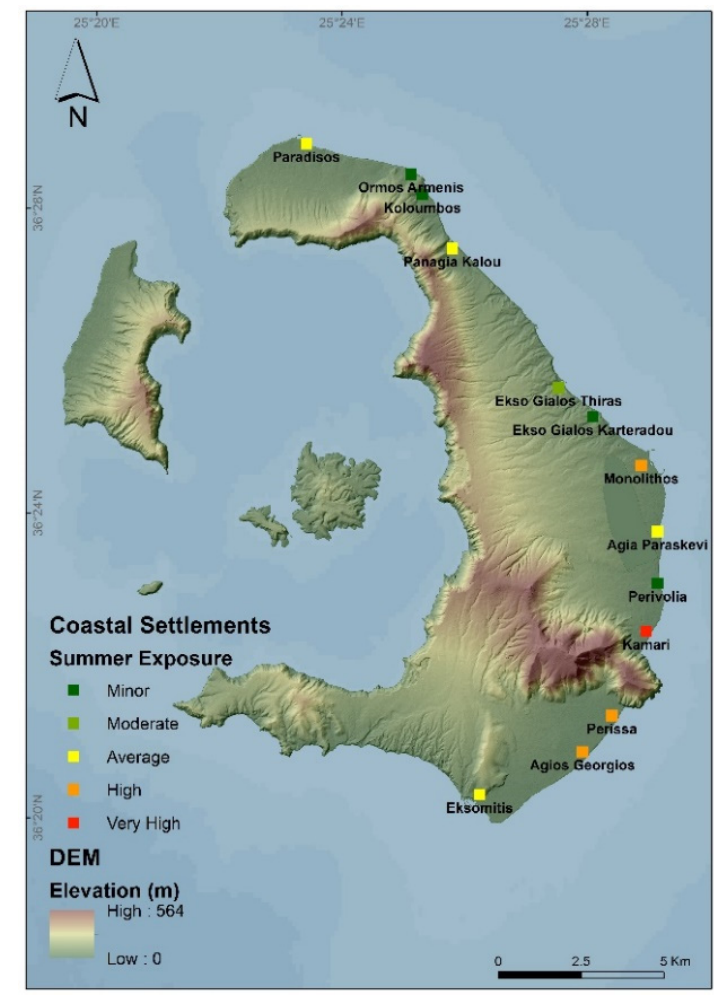

(b)

Figure 3. Total Exposure to natural hazards of the coastal settlements of Santorini in: (a) winter and (b) in summer. 


\subsection{Tsunami Run-up Scenario}

To implement the vulnerability assessment methodology in the settlements of the eastern coast of Santorini, it is initially necessary to determine the inundation zone of the study area that is expected to be affected by a destructive tsunami event. A "worst case run-up scenario" was developed by using a static inundation method and based on previous scientific evidence on seismicity in tectonic plate boundaries that associates earthquakes' magnitude to tsunami run-up. According to Iida (1963) [38], tsunamis triggered by an earthquake of magnitude $\mathrm{M}_{\mathrm{W}} \sim 8.5$ can create a wave with a mean maximum run-up of $10 \mathrm{~m}$ a.s.l. Moreover, evidence of $10 \mathrm{~m}$ run-up was confirmed by various studies $[5,11,35]$ conducted in coastal areas of the Cyclades islands complex. Accordingly, a $10 \mathrm{~m}$ run-up scenario was adopted in this study.

Based on this scenario, the inundation zone is delimited by the area with an elevation less than the maximum expected run-up. A high resolution ( $5 \mathrm{~m}$ ) Digital Elevation Model (DEM) was manipulated in a GIS software (ArcGIS/ArcMap ESRI $($ ), and the elevation pixel values were converted to inundation depths. According to PTVA model the hydrodynamic impact of the tsunami wave on the buildings is expressed through the inundation depth. Hydrodynamic characteristics of the inundation flows, such as the flow velocity and the turbulence, and their potential for causing building damage are already included in the model's core design through the weighting of attributes, which are utilized after field observations in building damage from past tsunami events. Figure 4 depicts the inundation zone and the depths of the flood flows in both the entire island and Kamari settlement. The areas that are expected to be significantly affected are the central and southern parts of the eastern coast of Santorini. The calculations reveal that, in Kamari, the maximum inundation reaches $493 \mathrm{~m}$ inland, while the mean inundation depth is $4.6 \mathrm{~m}$. Out of the total 849 buildings in the settlement that were recorded in the "2011 Building Census" [47], 423 buildings were found to be within the inundation zone, indicating that almost half of the buildings are expected to be affected. Almost half of these are located at inundation depths between 7 and $9 \mathrm{~m}$. Moreover, 373 buildings are characterized as single-use, and the other 50 buildings were characterized as mixed-use. Tables 1 and 2 portray the number of the inundated buildings and their use within the inundation zone, which are classified according to the inundation depth.

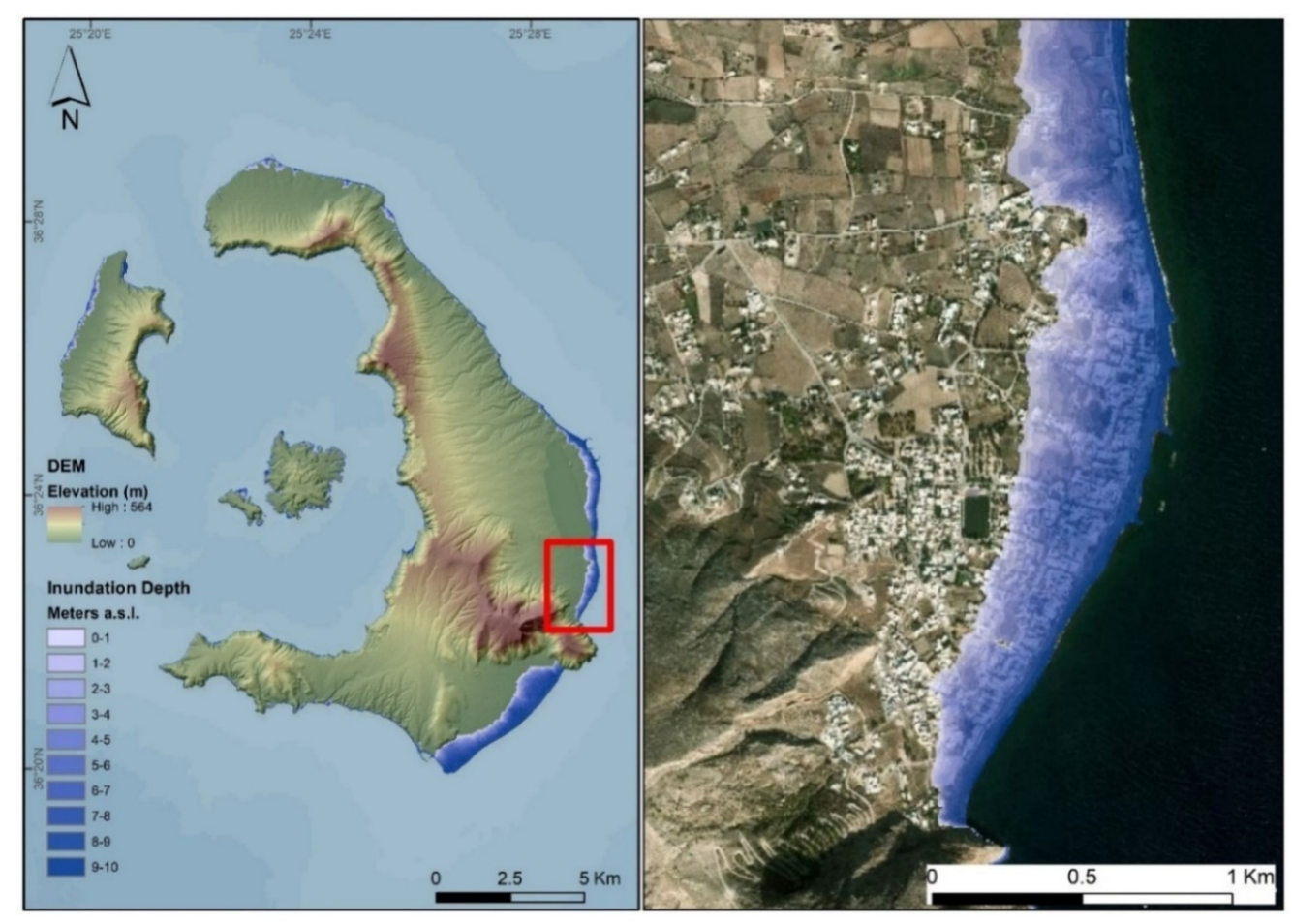

Figure 4. The inundation zone after a $10 \mathrm{~m}$ tsunami run-up in Santorini (left) and in Kamari (right). 
Table 1. Number of buildings per inundation depth.

\begin{tabular}{cccc}
\hline Inundation Depth $(\mathbf{m})$ & Number of Buildings & Cumulative Frequency & Cumulative Frequency \% \\
\hline $\mathbf{9 - 1 0}$ & 0 & 0 & 0 \\
$\mathbf{8 - 9}$ & 33 & 33 & 7.8 \\
$\mathbf{7 - 8}$ & 88 & 121 & 28.6 \\
$\mathbf{6}-\mathbf{7}$ & 80 & 201 & 47.5 \\
$\mathbf{5}-\mathbf{6}$ & 40 & 241 & 57.0 \\
$\mathbf{4}-\mathbf{5}$ & 33 & 274 & 64.8 \\
$\mathbf{3}-\mathbf{4}$ & $\mathbf{2 8}$ & 302 & 71.4 \\
$\mathbf{2}-\mathbf{3}$ & 37 & 339 & 80.1 \\
$\mathbf{1 - 2}$ & 35 & 374 & 88.4 \\
$\mathbf{0 - 1}$ & 49 & 423 & 100 \\
\hline
\end{tabular}

Table 2. Use of buildings in relation to inundation depth.

\begin{tabular}{|c|c|c|c|c|c|c|c|}
\hline \multicolumn{8}{|c|}{ Single-use } \\
\hline $\begin{array}{l}\text { Inundation } \\
\text { depth }(\mathrm{m})\end{array}$ & Dwelling & Hotel & Restaurant & Retail & Religious & Storage & Unknown \\
\hline 9-10 & 0 & 0 & 0 & 0 & 0 & 0 & 0 \\
\hline $8-9$ & 5 & 10 & 6 & 7 & 0 & 0 & 0 \\
\hline $7-8$ & 16 & 23 & 22 & 14 & 0 & 3 & 2 \\
\hline $6-7$ & 12 & 35 & 7 & 14 & 1 & 1 & 1 \\
\hline $5-6$ & 11 & 19 & 1 & 3 & 0 & 2 & 0 \\
\hline $4-5$ & 7 & 14 & 2 & 1 & 0 & 1 & 1 \\
\hline $3-4$ & 5 & 11 & 5 & 5 & 0 & 0 & 0 \\
\hline $2-3$ & 12 & 11 & 3 & 4 & 2 & 2 & 0 \\
\hline $1-2$ & 15 & 10 & 2 & 3 & 1 & 1 & 1 \\
\hline $0-1$ & 20 & 13 & 0 & 4 & 0 & 0 & 2 \\
\hline Total & 103 & 146 & 48 & 55 & 4 & 10 & 7 \\
\hline \multicolumn{8}{|c|}{ Mixed-use } \\
\hline $\begin{array}{l}\text { Inundation } \\
\text { depth (m) }\end{array}$ & $\begin{array}{c}\text { Retail/ } \\
\text { Dwelling }\end{array}$ & $\begin{array}{c}\text { Retail/ } \\
\text { Restaurant }\end{array}$ & $\begin{array}{c}\text { Retail/ } \\
\text { Hotel }\end{array}$ & \multicolumn{2}{|c|}{ Restaurant/Dwelling } & $\begin{array}{c}\text { Restaurant/ } \\
\text { Hotel }\end{array}$ & $\begin{array}{c}\text { Hotel/ } \\
\text { Dwelling }\end{array}$ \\
\hline 9-10 & 0 & 0 & 0 & \multicolumn{2}{|c|}{0} & 0 & 0 \\
\hline $8-9$ & 0 & 0 & 1 & \multicolumn{2}{|c|}{0} & 4 & 0 \\
\hline $7-8$ & 3 & 1 & 2 & \multicolumn{2}{|c|}{1} & 0 & 1 \\
\hline $6-7$ & 5 & 1 & 0 & \multicolumn{2}{|c|}{1} & 2 & 0 \\
\hline $5-6$ & 3 & 0 & 0 & \multicolumn{2}{|c|}{0} & 1 & 1 \\
\hline $4-5$ & 4 & 0 & 2 & \multicolumn{2}{|c|}{0} & 0 & 0 \\
\hline $3-4$ & 2 & 0 & 0 & \multicolumn{2}{|c|}{0} & 0 & 0 \\
\hline $2-3$ & 0 & 1 & 0 & \multicolumn{2}{|c|}{1} & 0 & 1 \\
\hline $1-2$ & 3 & 0 & 0 & \multicolumn{2}{|c|}{0} & 0 & 1 \\
\hline $0-1$ & 4 & 1 & 1 & \multicolumn{2}{|c|}{1} & 0 & 1 \\
\hline Total & 24 & 4 & 6 & \multicolumn{2}{|c|}{4} & 7 & 5 \\
\hline
\end{tabular}

\subsection{Building Vulnerability Assessment}

In order to achieve the objective of this study, which is to quantify the building stock's vulnerability to tsunami at a settlement level, the Papathoma Tsunami Vulnerability Assessment (PTVA-4) analytical model was applied. The PTVA model is designed to provide estimates of the relative building vulnerability to tsunami hazard. The PTVA was selected as it takes into account a variety of parameters for the calculation of the relative vulnerability of each building, as shown in Figure 5. The PTVA model has been applied in studies in various countries, since the wide range of parameters it takes into account can be applied to any building around the world [52-54]. The weighting of these parameters derived from an Analytic Hierarchy Process (AHP) with the participation of experts, contributing their experience in consequences in buildings from catastrophic tsunami events around the world [36]. It is a multi-criteria evaluation tool, where the analysis is performed by a GIS software. The availability 
along with the easy access to the required information material and the ease of calculations, render the model adequately functional. Furthermore, the ability to update and extend the database that is used by this approach, makes this analytical model a dynamic tool. The PTVA model was introduced by Papathoma (2003) [55], and since then, the model has been revised and upgraded three times [36,56-58]. The latest version of the model PTVA-4 was used in this study.

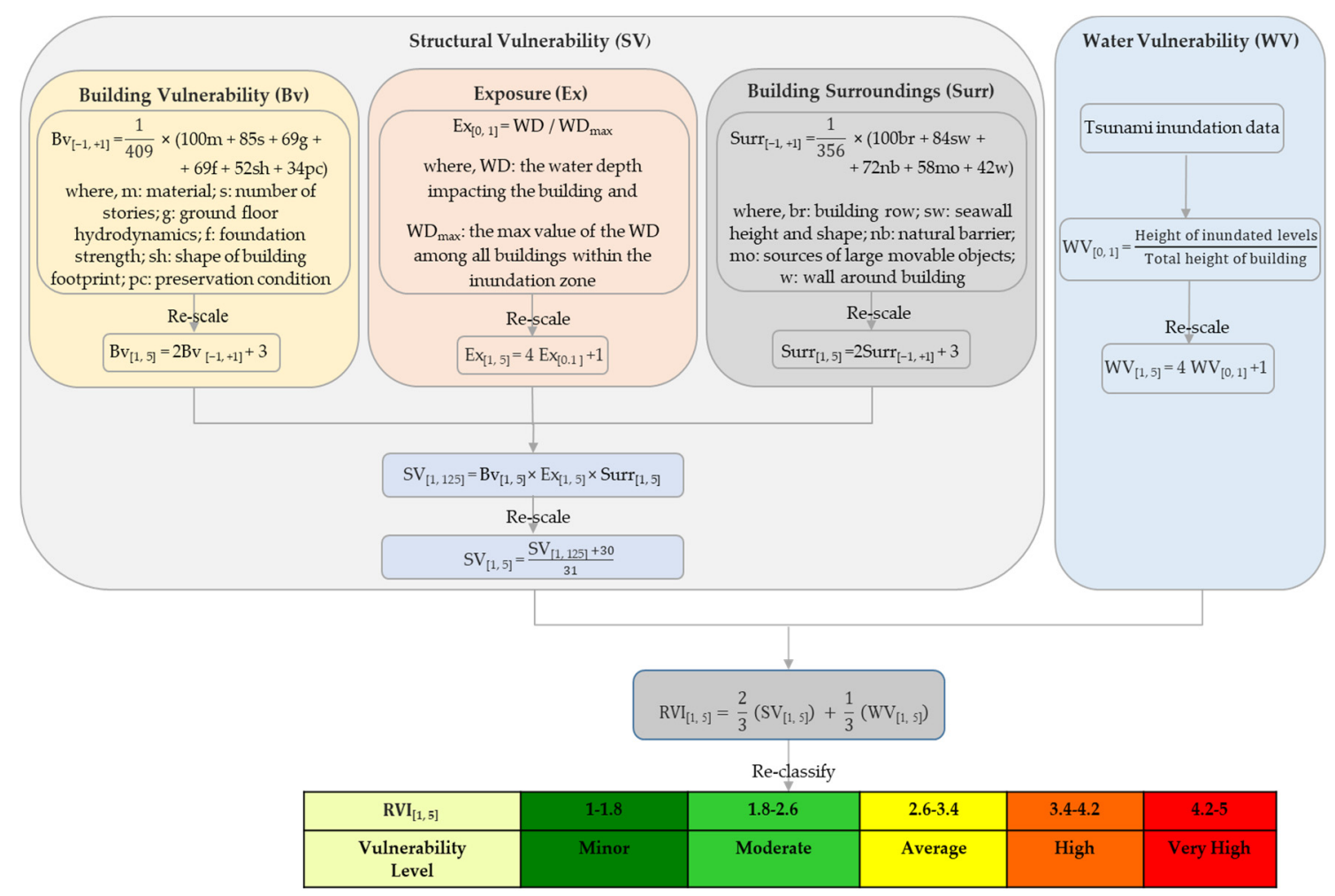

Figure 5. The PTVA-4 model framework.

The application of the PTVA model presupposes the design of the database, from which the values of the individual attributes used for the calculations, are drawn. The information used by the model concerns the building stock data as well as the characteristics of the surrounding environment of the building and the inundation depth [36]. PTVA calculates each building's numerical index, referred to as the Relative Vulnerability Index (RVI) which ranges from 1 (minor) to 5 (very high). The reference level for implementing this model, requires the organization of information for each building. Some information about the characteristics of the buildings (such as the ground floor hydrodynamics, the shape of the building footprint, the building row, etc.), was retrieved from satellite images, while others (e.g., the number of stories, the preservation condition, and the sources of large moveable objects) were collected through on-site observation. For this reason, a field survey was carried out in the settlement of Kamari in order to catalogue the necessary attributes of the predefined parameters of the model for each building and to identify its use.

\section{Results and Discussion}

\subsection{Structural and Water Vulnerability}

Kamari developed as a settlement mainly after the 1956 earthquake, due to the relocation of the population from other settlements of the island that were destroyed by the earthquake. The majority of the buildings in Kamari ( $82 \%$ of the building stock) were built after the first Greek Anti-Seismic Regulation, which was stated in 1959 [47]. The main construction materials of the buildings are reinforced concrete for the skeleton frame, and brick walls for the building shell. 
The field survey showed that five buildings that were constructed mainly from reinforced concrete are characterized according to PTVA- 4 as minor vulnerability, 365 brick wall buildings have an average vulnerability, whereas 53 buildings constructed from other materials have very high vulnerability. The maximum number of stories recorded in the study area was three, as a result of the building height restrictions. In summary, 147 one-story buildings were recorded, 254 with two stories, and 22 with three stories, labeled as very high, high, and average vulnerability, respectively. Regarding ground floor hydrodynamics, the buildings represent the typical architecture of Greek islands, without an open plan ground floor, but with many open-breakable accesses, such as doors and windows. This fact increases the wave impact, since the hydrodynamic pressure could cause damage to the building shell. Exceptions included some hotels and restaurants found on the coastal front of the settlement, the ground floor of which is surrounded by glass windows. Thus, $75 \%$ of the buildings were characterized as of high or very high vulnerability score.

Regarding the building foundation, 271 buildings were reported to have deep pile foundation, 91 with average depth foundation, and 61 with shallow foundation, a fact that characterizes the buildings as minor, average and very high vulnerability, respectively. The shallow foundation buildings, mostly food facilities, which were scored as having the highest vulnerability, were found in the first row of buildings on the coastal front of the settlement. As for the shape of the building footprint, the majority of the buildings have rectangular (104 buildings) or lengthened rectangular (233 buildings) shape, attaining average and high vulnerability scores. In regard to the preservation condition, 303 buildings are characterized as minor and moderate vulnerability, 102 buildings are characterized as average, and 18 buildings are characterized as high or very high vulnerability. The building vulnerability $(\mathrm{Bv})$ component of the model, consists of the above-mentioned attributes, and as shown in Figure 6a. In total, 300 buildings are characterized as having an average vulnerability and 109 as highly vulnerable, while 6 scored as very highly vulnerable and 8 as moderately vulnerable. There were no buildings found as having minor vulnerability. The analysis of the Bv component that also represents more or less the techniques of architecture and the construction technique, portrays the prevalence of the characteristics of the buildings in Kamari which negatively affect the vulnerability to tsunami.

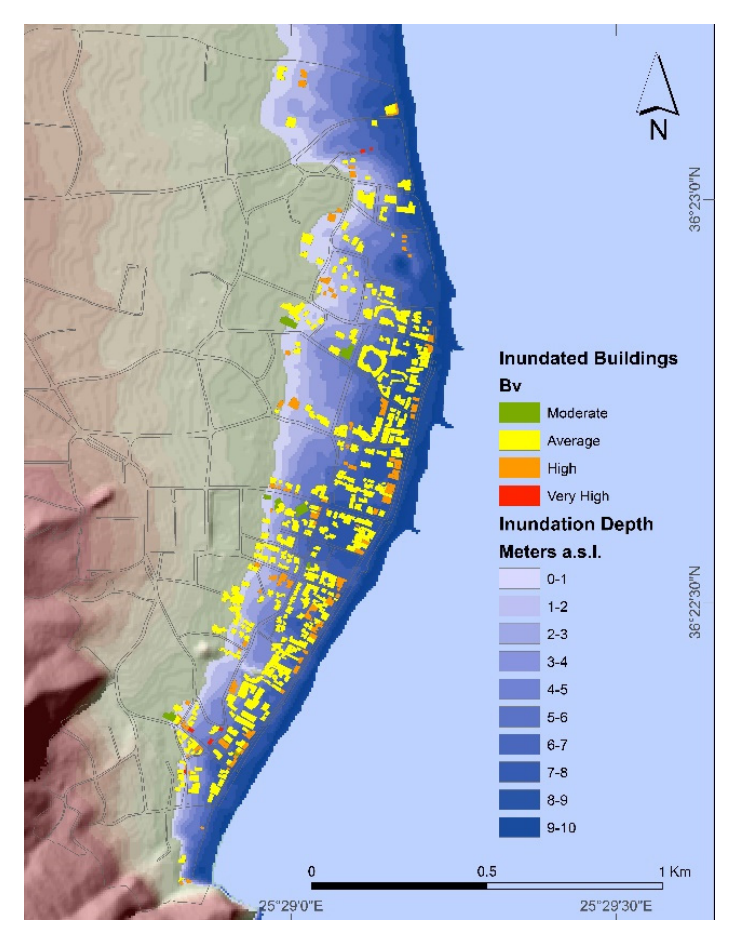

(a)

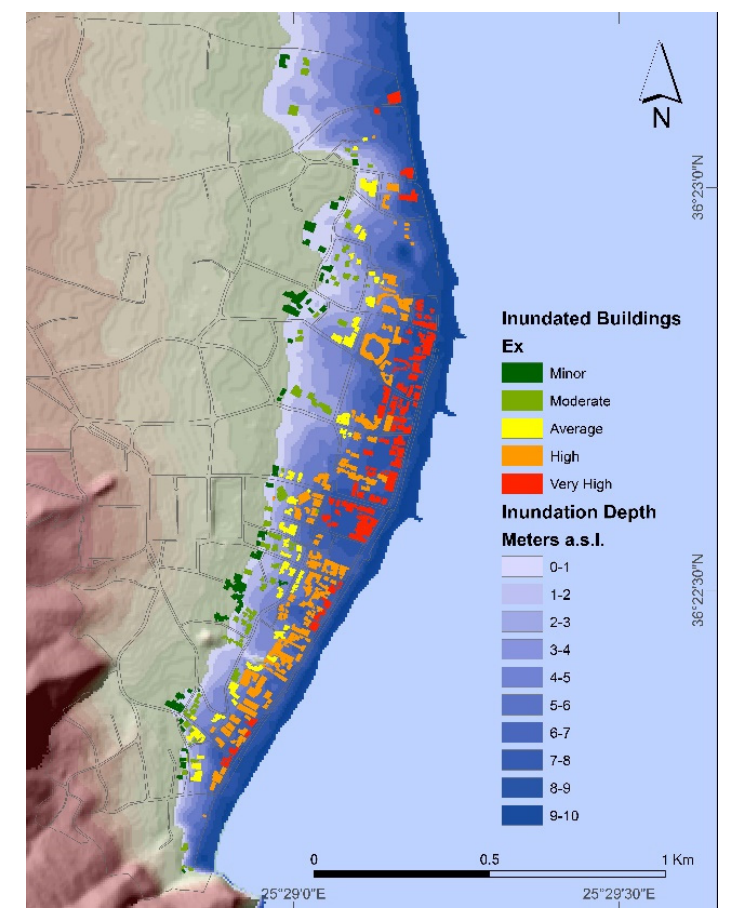

(b)

Figure 6. Cont. 


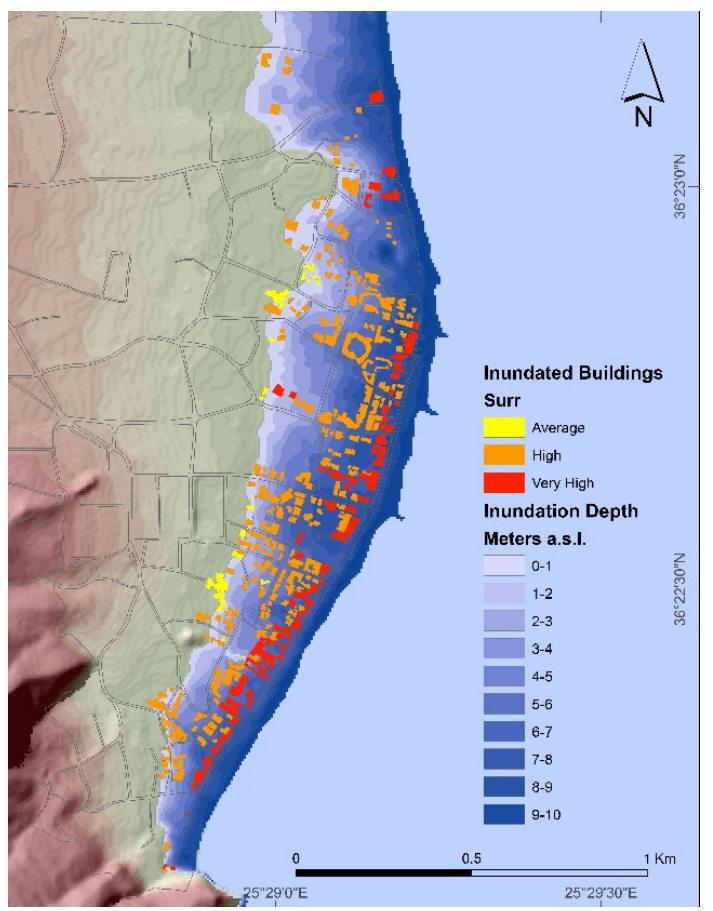

(c)

Figure 6. Maps depicting the spatial distribution of: (a) building vulnerability (Bv); (b) exposure (Ex); (c) surrounding characteristics (Surr) components.

Exposure (Ex) is the second component of the PTVA-4 model that was calculated, and it expresses the ratio between the water depth impacting the building, and the maximum effective water depth in the study area [36]. Figure $6 \mathrm{~b}$ portrays the distribution of vulnerability to water exposure in comparison with the inundation depth. In total, $91 \%$ of the total buildings were labeled as having high scores of vulnerability ( 284 very high, 58 high, and 45 average vulnerability), while the remaining buildings scored as having low vulnerability ( 35 moderate and 1 minor). The results reveal that the buildings in the northern part of the settlement are characterized with higher vulnerability. This fact is linked to the surface topography since, in the northern part, the slope appears to be lower than in the southern part.

Examining the protection the surrounding gives to the buildings, the building surroundings (Surr) component revealed that 128 buildings that were found lined in the first row along the shoreline have very high vulnerability score, 131 buildings that were lined in the second and third row have high vulnerability score, 122 between the fourth and sixth row have average vulnerability, 41 between the seventh and the tenth row with moderate vulnerability and one building beyond the tenth row scored as minor vulnerability. The absence of a sea wall and natural barriers results in an increase in vulnerability of the buildings, and characterizes them, according to the model, as very highly vulnerable. Moreover, the presence of sources of large moveable objects, such as cars, and the existence of constructions that are susceptible to waves along the coastal front, raises the risk for the buildings (Figure 7). Therefore, 43 buildings exhibit very high, 338 exhibit average, and 12 exhibit minor vulnerability (Figure 6c). 

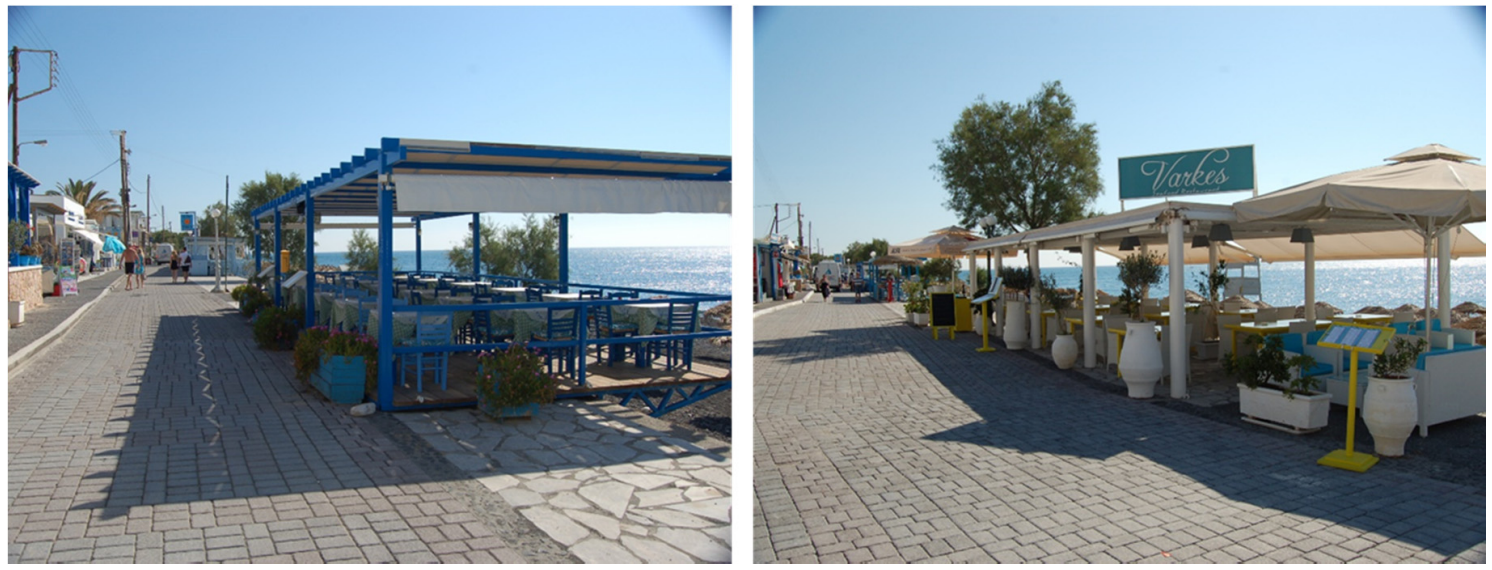

Figure 7. Characteristic structures in the coastal front of the settlement with high risk of drifting due to a tsunami wave, increasing the possibility of damage in the surrounding buildings.

The Structural Vulnerability (SV), a factor of the PTVA-4 model, is the multiplication of the Bv, Ex and Surr components, and expresses the result of the vulnerability of the building itself, the building exposure to the inundation scenario and the building surroundings [36]. Within the inundation zone, 51 buildings were labeled as having a high SV score, 201 as average, 121 as moderate and 50 as minor SV score. No buildings were considered as having very high vulnerability (Figure 8a).

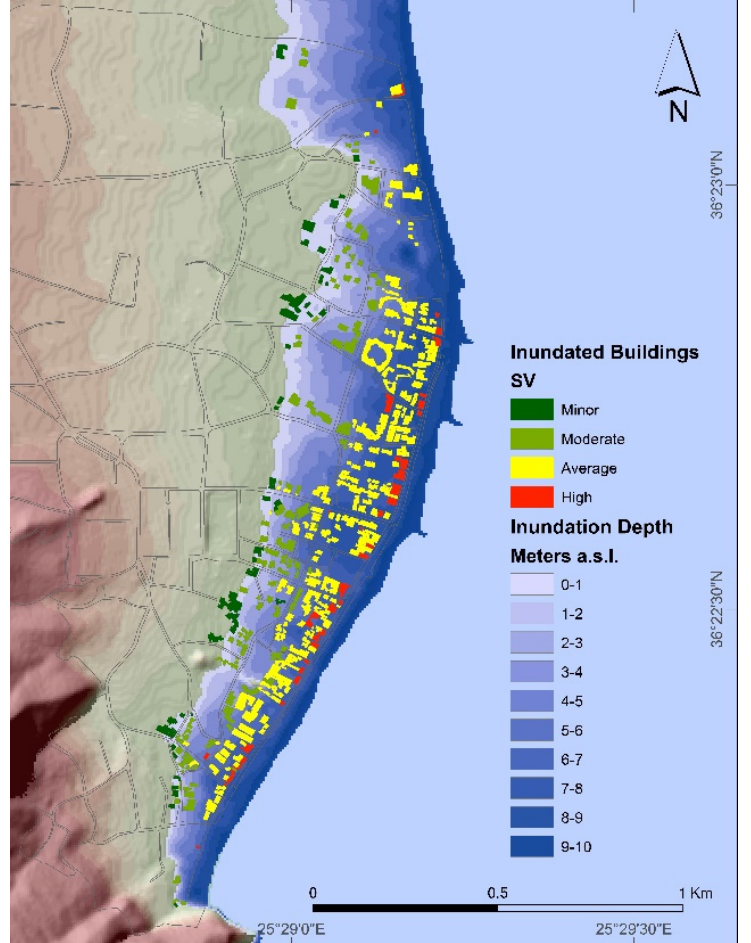

(a)

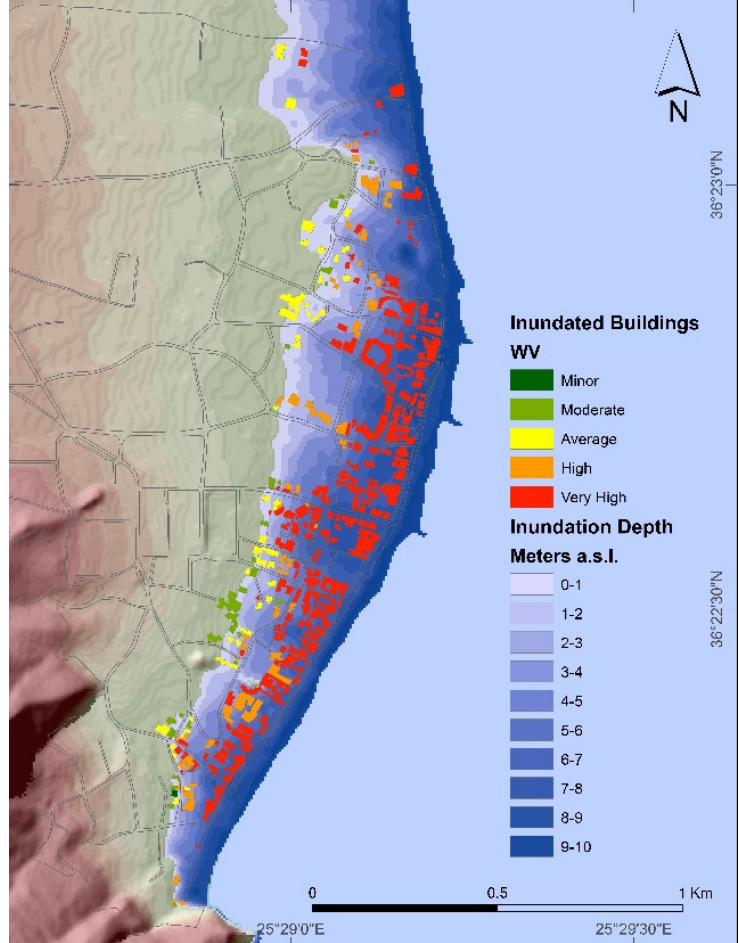

(b)

Figure 8. Maps depicting the spatial distribution of: (a) Structural Vulnerability (SV) and (b) Water Vulnerability (WV) factors.

As for the Water Vulnerability (WV) factor, the height restriction law and the existence of basements (Figure 9) in some of the buildings led to an increased vulnerability. The survey found that 342 buildings have high or very high vulnerability score, whereas 81 buildings that are located towards the end of the inundation zone, have average to minor vulnerability (Figure 8b). 

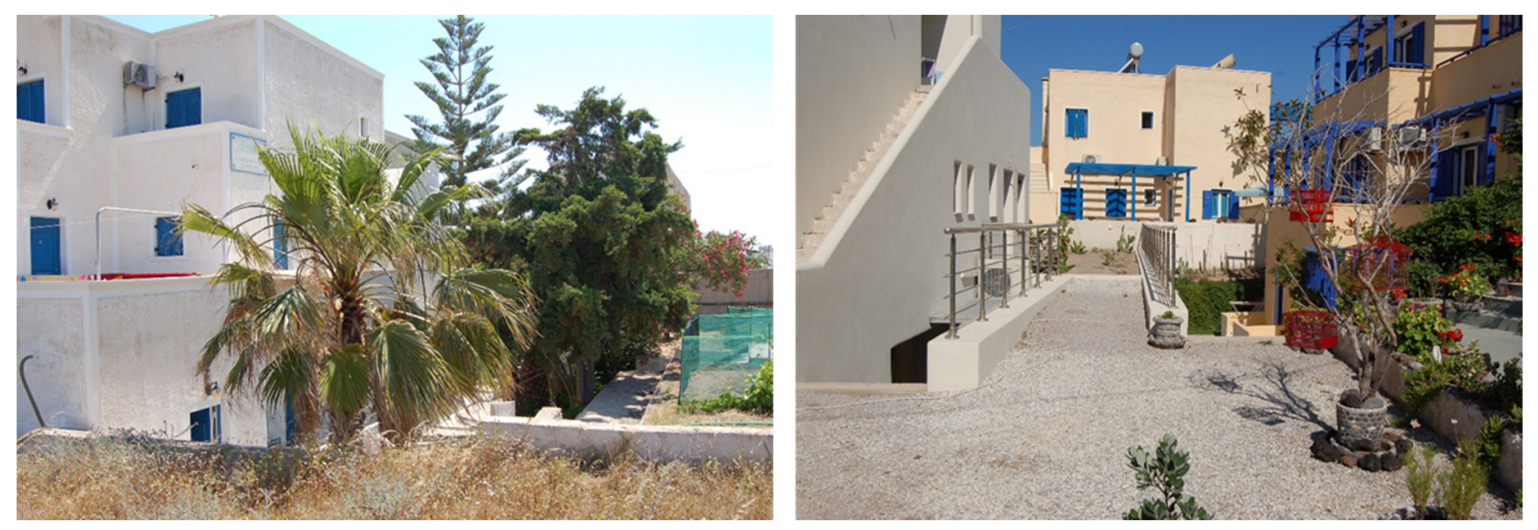

Figure 9. Buildings with basements found in the south (left) and central (right) part of Kamari.

\subsection{Relative Vulnerability Index and Building Use}

The RVI scores, classified with the "Natural Breaks (Jenks)" method, revealed that 51 out of the 423 buildings were considered as having very high vulnerability to tsunamis. These buildings are found mainly in the first two rows facing the coastline, presenting a linear pattern. The highly vulnerable buildings totaled 195, and are clustered between the 5 and $9 \mathrm{~m}$ depth of the inundation flows. There are 94 buildings that are considered as having average vulnerability, found between 3 and $5 \mathrm{~m}$ of flood depth. The buildings labeled as moderate and minor vulnerability ( 35 and 48 , respectively) are located towards the end of the inundation zone, within water depths between 1 and $2 \mathrm{~m}$ (Figure 10).

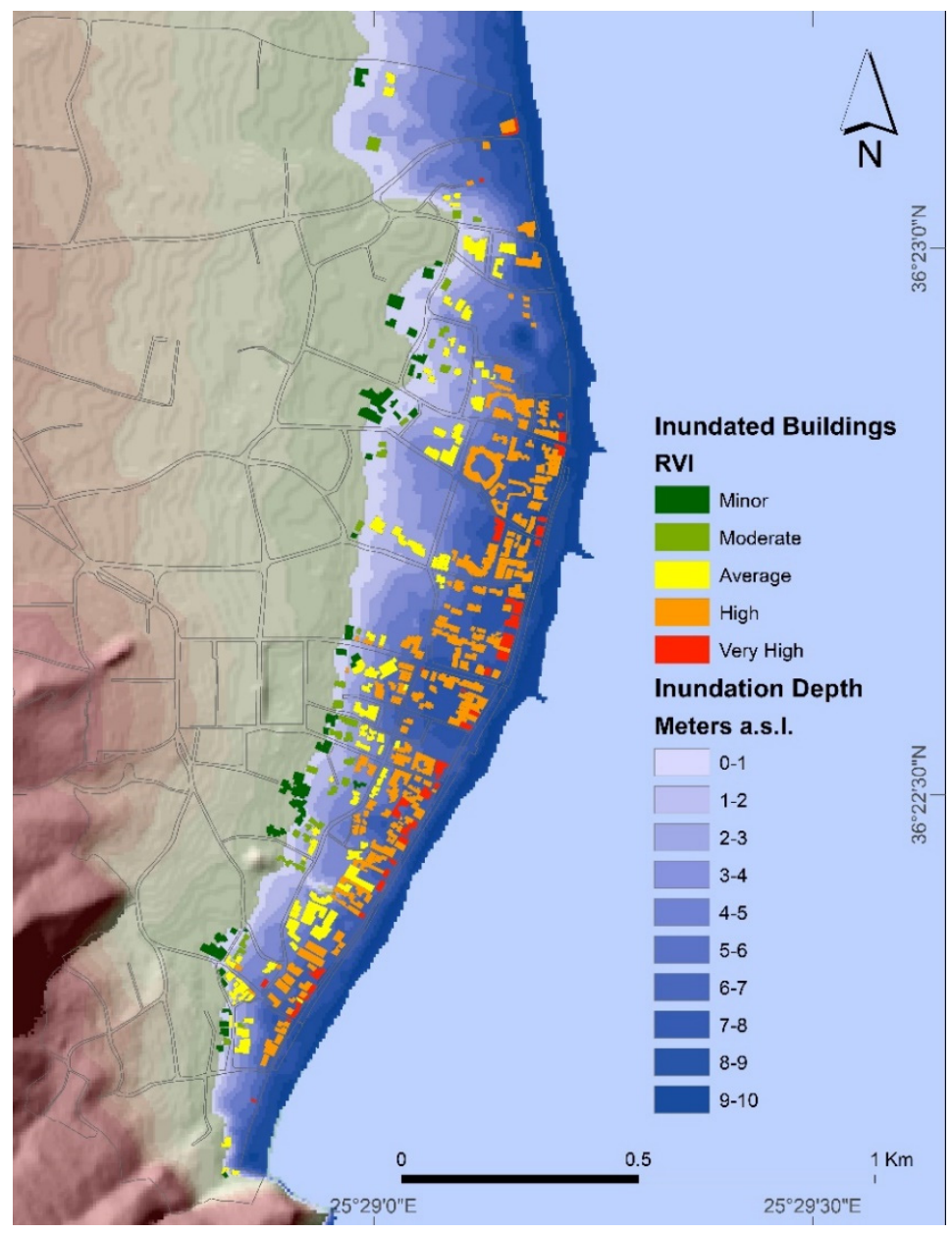

Figure 10. Spatial distribution of the Relative Vulnerability Index (RVI). 
In summary, more than half (58\%) of the buildings of the settlement are characterized as having a high to very high level of vulnerability (Figure 11). The corresponding percentage of buildings with minor or moderate vulnerability is $20 \%$. Buildings with average vulnerability account for $22 \%$. As Figure 12 depicts, the maximum values of the two classes with the highest (high and very high) vulnerability are recorded in the flood depths of 7 and $8 \mathrm{~m}$, respectively. The frequency of the buildings that scored as having high and very high vulnerability, decreases as the distance from the coastline increases, taking a value of 0 at depths of 3 and $5 \mathrm{~m}$, respectively. The spatial distribution of the class of average vulnerability presents two local maxima at the depths of 3 and $5 \mathrm{~m}$. Buildings characterized by the lowest levels of vulnerability are located at the highest elevations of the flood zone, where the dynamics of flood flows appear more weakened. These buildings are mainly distributed at the flood flow limit.

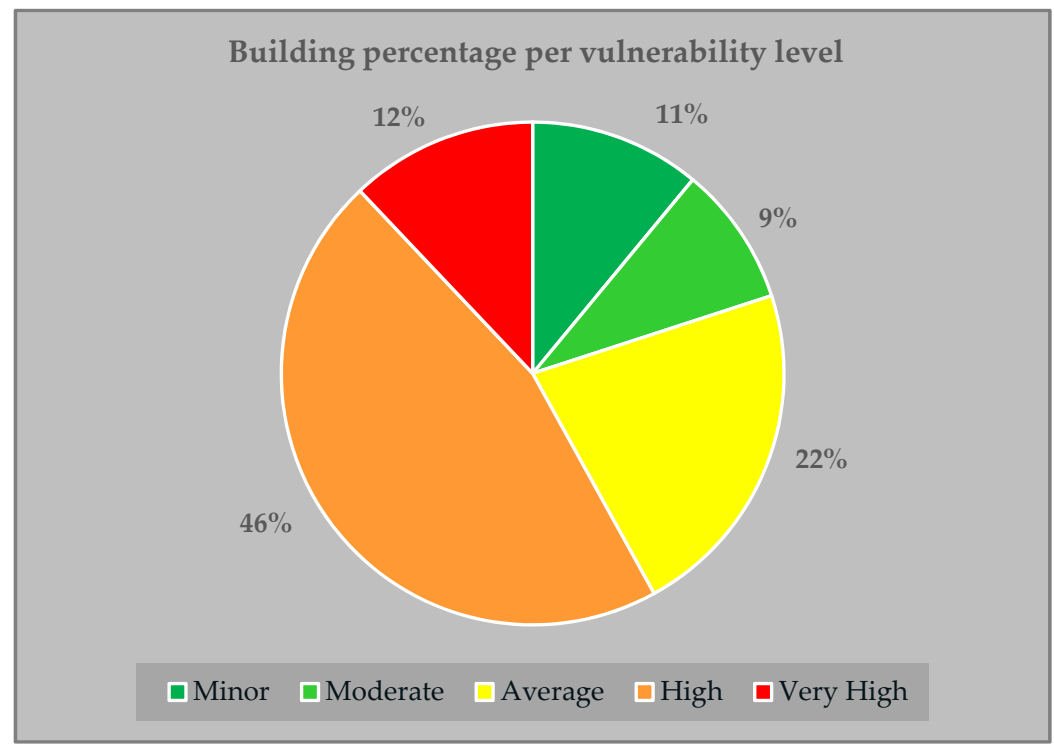

Figure 11. Relative Vulnerability Index (RVI) percentage per vulnerability level.

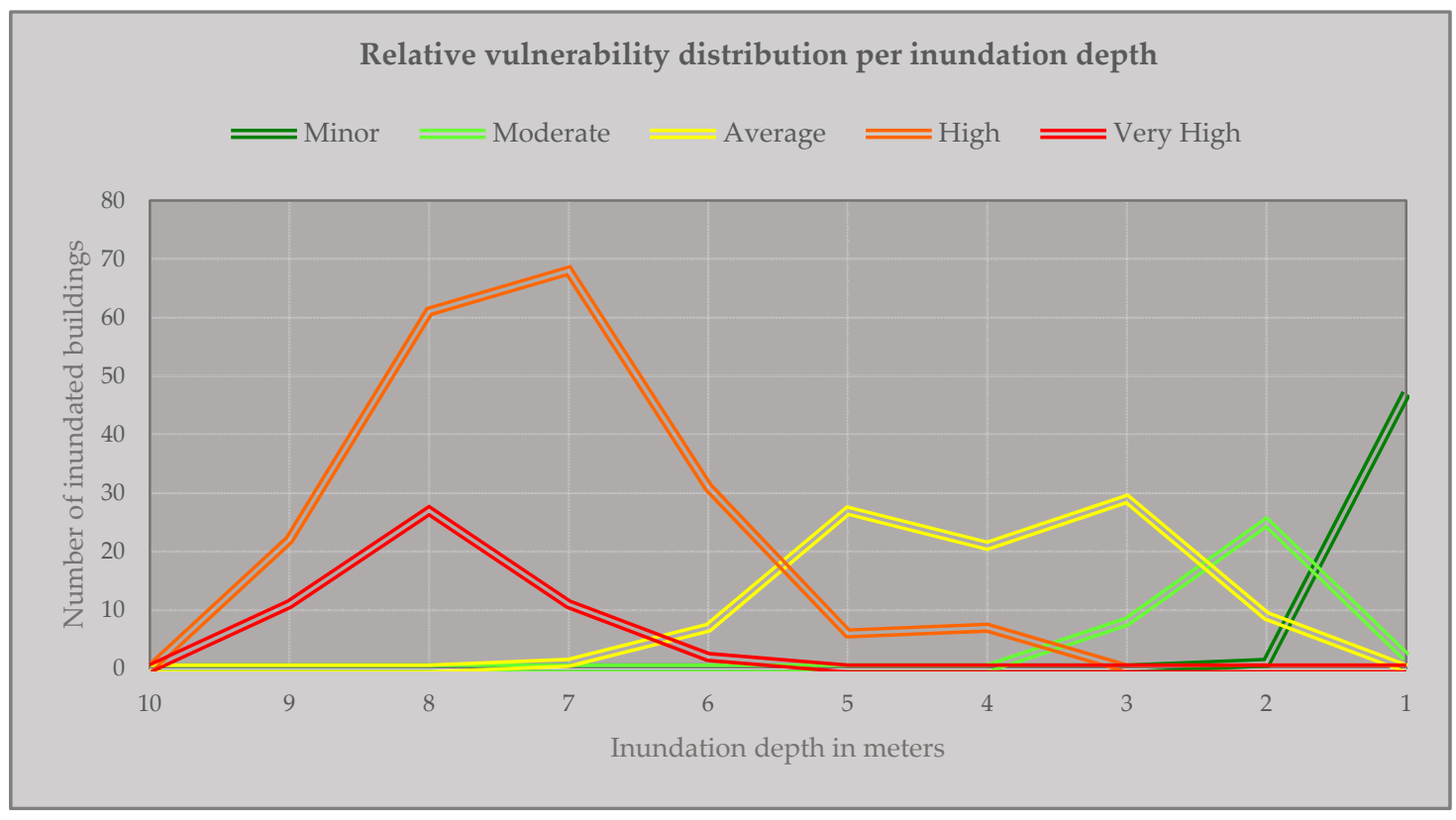

Figure 12. Diagram depicting the building vulnerability level in relation to inundation depth. Value 10 on the $x$-axis represents the coastline and value 1 represents the end of the inundation zone. 
Relating the use of the buildings to the level of vulnerability (Table 3), it is found that $42 \%$ of dwellings are characterized by high and very high relative vulnerability. The corresponding percentage for hotels is $57 \%$, accounting for 82 out of 146 buildings. Retail and restaurants record the highest values in the high and very high vulnerability classes with $62 \%$ and $90 \%$, respectively, which is explained by the spatial polarization of the development of economic activity along the coastal front.

Table 3. Relative Vulnerability Index (RVI) in relation to the use of the buildings.

\begin{tabular}{|c|c|c|c|c|c|c|}
\hline & \multirow[b]{2}{*}{$\begin{array}{l}\text { Number of } \\
\text { Buildings per Use }\end{array}$} & \multicolumn{5}{|c|}{ Relative Vulnerability Index (RVI) } \\
\hline & & Minor & Moderate & Average & High & Very High \\
\hline \multicolumn{7}{|c|}{ Single-use } \\
\hline Dwelling & 103 & 18 & 16 & 24 & 42 & 3 \\
\hline Hotels & 146 & 13 & 14 & 37 & 80 & 2 \\
\hline Restaurant & 48 & 0 & 0 & 6 & 18 & 24 \\
\hline Retail & 55 & 4 & 0 & 11 & 21 & 19 \\
\hline Religious & 4 & 1 & 0 & 2 & 1 & 0 \\
\hline Storage & 10 & 1 & 0 & 2 & 4 & 3 \\
\hline Unknown & 7 & 2 & 1 & 0 & 4 & 0 \\
\hline \multicolumn{7}{|c|}{ Mixed-use } \\
\hline Retail/Dwelling & 24 & 5 & 2 & 7 & 10 & 0 \\
\hline Retail/Restaurant & 4 & 1 & 1 & 0 & 2 & 0 \\
\hline Retail/Hotel & 6 & 1 & 0 & 2 & 3 & 0 \\
\hline Restaurant/Dwelling & 4 & 1 & 0 & 1 & 2 & 0 \\
\hline Restaurant/Hotel & 7 & 0 & 0 & 0 & 7 & 0 \\
\hline Hotel/Dwelling & 5 & 1 & 1 & 2 & 1 & 0 \\
\hline Total & 423 & 48 & 35 & 94 & 195 & 51 \\
\hline
\end{tabular}

\section{Conclusions}

The Southern Aegean Sea is an area prone to tsunamis. A review of the catalogues of past events, supplemented by historical records and research findings, shows that the geodynamic setting of the wider area renders it an active tsunamigenic zone. Earthquakes, volcanic activity and submarine landslides can trigger tsunami waves capable of causing severe damage to the coasts of the Eastern Mediterranean Sea. The proximity of Santorini Island to the Hellenic subduction zone, as well as to other active features, combined with the geography of the island and the exposure of human structures and systems to tsunamis, are the main reasons for the increased vulnerability of the coastal settlements of the island. This study focused on the assessment of the buildings' vulnerability to tsunamis in Kamari, which is the coastal settlement with the highest exposure to natural hazards, as the exposure analysis in this study revealed. In order to assess the building vulnerability, a $10 \mathrm{~m}$ tsunami run-up "scenario" was developed. The PTVA-4 model was applied to the buildings of the settlement, which are expected to be within the inundation zone. A plethora of attributes (i.e., building material, ground floor hydrodynamics, height of the building, level of protection against the tsunami waves, etc.), in addition to the characteristics of the inundation, were analyzed by the model. It seems that they positively contribute to the increase in building vulnerability in Kamari. The Relative Vulnerability Index (RVI) estimation revealed that 246 out of 423 buildings are rated as highly or very highly vulnerable and are mostly located on the coastal front of the settlement. According to building use, dwellings and hotels proved to display higher vulnerability scores in comparison to other building uses.

In light of these results, the lack of tsunami building codes in Greece, designed to reduce the impact of a tsunami wave in constructions, should be seriously considered. A set of regulations for constructions could be introduced, including measures for building protection based on the PTVA-4 application aftermath and its results. Therefore, some recommendations could include the encouragement of using reinforced concrete as the main construction material in the new buildings. 
The PTVA-4 results showed that buildings built solely from reinforced concrete appears to have the lowest vulnerability compared with buildings built from mixed materials, including bricks or wood in the buildings' shell. Regarding ground floor hydrodynamics, the lower level of the buildings could be designed to allow waves to pass through the ground floor, a feature already present in a few buildings hosting tourist facilities in Kamari. As for the shape of the building footprint, it is preferable to use geometries, such as lengthened rectangular constructions with the main side perpendicular to the coastline, in order to reduce the hydrodynamic pressure of the inundation flows. However, the limitation of such a building geometry is that the view from the inside will be compromised. It is also preferable to avoid having buildings with floors below the ground levels and to encourage the construction of protective walls around the buildings, such as garden walls. Another recommendation regarding the surrounding protection of the buildings is to remove land uses (such as car parking spaces and the susceptible constructions of the coastal front) outside of the inundation zone, in order to reduce further damage in the buildings from the impact of the debris flow and the movable objects. An additional recommendation could be the construction of a submerged wave barrier (without degrading the landscape) to reflect a significant amount of the energy of the tsunami back into the open sea and reduce the impact on the coast.

As evidenced by the results of the PTVA-4 model implementation, an increased level of vulnerability characterizes many of the buildings of the coastal zone. The predominant use of these buildings is related to economic activity and touristic development. In case of extreme event occurrence, high vulnerability to tsunamis is likely to contribute to the loss of the local comparative advantage of Kamari. Therefore, this fact is expected to increase the potential for declining tourism development and the need to absorb financial resources for restoration and recovery. Therefore, further research on how to increase the resilience of the settlement is needed.

The PTVA-4 model is a valuable tool in investigating vulnerability in high disaster risk coastal areas. It is a tool which can be included in mitigation strategies against tsunami hazard globally and particularly in Greece. Future studies could combine PTVA model with more sophisticated methodologies, such as empirical vulnerability functions, to closely examine the building damage from a tsunami impact [59]. Moreover, methodologies, such as that of Bressan et al. (2018) [60], which describe the transport processes of objects from extreme marine events could be used for further investigation in building damages from moveable objects. Furthermore, a newer version of the PTVA model could consider human population aspects, to provide additional insights when understanding spatiotemporal aspects of the human presence in coastal vulnerability. An integrated model combining the PTVA-4 with population characteristics data, could be a useful tool also for tsunami early warning systems.

A main limitation of the study is the "bathtub" approach of a worst-case tsunami scenario which was utilized. This approach has had numerous applications in the past and it pairs well with the PTVA model, as its framework inherently considers attributes of flow hydrodynamics, such as the building shape, ground floor plan, foundations, the presence of walls, seawalls and the proximity to movable objects. However, a tsunami inundation flow simulation could provide more accurate data on the inundation depth and the hydrodynamics of the flow, since these are important characteristics that are taken into account in the implication of the PTVA-4 model.

Author Contributions: Conceptualization, D.-V.B. and G.V.; methodology, D.-V.B., L.-M.M., G.V. and E.K.; software, D.-V.B., K.T. and M.A.; validation, D.-V.B., L.-M.M., G.V., K.T., M.A., I.T. and E.K.; formal analysis, D.-V.B., L.-M.M., G.V. and E.K.; investigation, D-V.B., L.-M.M., G.V., K.T., M.A., I.T. and E.K.; resources, D.-V.B., L.-M.M., G.V. and E.K.; data curation, D.-V.B.; writing—original draft preparation, D.-V.B., L.-M.M., G.V., K.T., M.A. and E.K.; writing-review and editing, D.-V.B., L.-M.M., G.V. and E.K., visualization, D.-V.B., L.-M.M. and G.V.; supervision, D.-V.B. and E.K. All authors have read and agreed to the published version of the manuscript.

Funding: This research received no external funding.

Acknowledgments: We would like to thank Dale Dominey-Howes and the two anonymous reviewers for their comments and suggestions that significantly improved the manuscript.

Conflicts of Interest: The authors declare no conflict of interest. 


\section{References}

1. Witter, R.C.; Kelsey, H.M.; Hemphill-Haley, E. Great Cascadia earthquakes and tsunamis of the past 6700 years, Coquille River estuary, southern coastal Oregon. Geol. Soc. Am. Bull. 2003, 115, 1289-1306. [CrossRef]

2. Cita, M.B.; Aloisi, G. Deep-sea tsunami deposits triggered by the explosion of Santorini (3500 y BP), eastern Mediterranean. Sediment. Geol. 2000, 135, 181-203. [CrossRef]

3. Jiang, L.; LeBlond, P.H. Three-dimensional modeling of tsunami generation due to a submarine mudslide. J. Phys. Oceanogr. 1994, 24, 559-572. [CrossRef]

4. Ambraseys, N.; Synolakis, C. Tsunami catalogs for the Eastern Mediterranean, revisited. J. Earthq. Eng. 2010, 14, 309-330. [CrossRef]

5. Dominey-Howes, D.; Cundy, A.; Croudace, I. High energy marine flood deposits on Astypalaea Island, Greece: Possible evidence for the AD 1956 southern Aegean tsunami. Mar. Geol. 2000, 163, 303-315. [CrossRef]

6. Bryant, E. Tsunami: The Underrated Hazard; Springer: Berlin/Heidelberg, Germany, 2014. [CrossRef]

7. Papadopoulos, G.; Gràcia, E.; Urgeles, R.; Sallares, V.; De Martini, P.M.; Pantosti, D.; González, M.; Yalciner, A.C.; Mascle, J.; Sakellariou, D.; et al. Historical and pre-historical tsunamis in the Mediterranean and its connected seas: Geological signatures, generation mechanisms and coastal impacts. Mar. Geol. 2014, 354, 81-109. [CrossRef]

8. Gauraz, A.L.; Valencia, N.; Koscielny, M.; Guillande, R.; Gardi, A.; Leone, F.; Salaun, T. Tsunami damages assessment: Vulnerability functions on buildings based on field and earth observation survey. Geophys. Res. Abstr. 2009, EGU2009-5785.

9. Kelsey, H.M.; Witter, R.C.; Hemphill-Haley, E. Plate-boundary earthquakes and tsunamis of the past $5500 \mathrm{yr}$, Sixes River estuary, southern Oregon. Geol. Soc. Am. Bull. 2002, 114, 298-314. [CrossRef]

10. Dominey-Howes, D. Assessment of tsunami magnitude and implications for urban hazard planning. Disaster Prev. Manag. 1998, 7, 176-182. [CrossRef]

11. Dominey-Howes, D. Documentary and geological records of tsunamis in the Aegean Sea region of Greece and their potential value to risk assessment and disaster management. Nat. Hazards 2002, 25, 195-224. [CrossRef]

12. Farreras, S.F. Post-tsunami field survey procedures: An outline. Nat. Hazards 2000, 21, 204-214. [CrossRef]

13. Furlani, S.; Biolchi, S.; Devoto, S.; Saliba, D.; Scicchitano, G. Large boulder along the NE Maltese coast: Tsunami or storm wave deposits? J. Coastal Res. 2011, 61, 470. [CrossRef]

14. Dominey-Howes, D. A re-analysis of the Late Bronze Age eruption and tsunami of Santorini, Greece, and the implications for the volcano-tsunami hazard. J. Volcanol. Geoth. Res. 2004, 130, 107-132. [CrossRef]

15. Shiki, T.; Cita, M.B. Tsunami-related sedimentary properties of Mediterranean homogenites as an example of deep-sea tsunamiite. In Tsunamiites; Elsevier: Amsterdam, The Netherlands, 2008; pp. 203-215. [CrossRef]

16. Willershäuser, T.; Vött, A.; Brückner, H.; Bareth, G.; Nelle, O.; Nadeau, M.J.; Hadler, H.; Ntageretzis, K. Holocene tsunami landfalls along the shores of the inner Gulf of Argostoli (Cefalonia Island, Greece). Zeitschrift für Geomorphol. 2013, 57, 105-138. [CrossRef]

17. Papadopoulos, G. Tsunamis in the European-Mediterranean Region: From Historical Record to Risk Mitigation, 1st ed.; Elsevier: Amsterdam, The Netherlands, 2015.

18. Tsanakas, K.; Karymbalis, E.; Cundy, A.; Gaki-Papanastassiou, K.; Papanastassiou, D.; Drinia, H.; Koskeridou, E.; Maroukian, H. Late Holocene geomorphic evolution of the Livadi coastl plain, Gulf of Argostoli, Cephalonia Island, Western Greece. Geogr. Fis. Din. Quat. 2019, 42, 45-61. [CrossRef]

19. Cantalamessa, G.; Di Celma, C. Sedimentary features of tsunami backwash deposits in a shallow marine Miocene setting, Mejillones Peninsula, northern Chile. Sediment. Geol. 2005, 178, 259-273. [CrossRef]

20. McCoy, F.W.; Heiken, G. Tsunami generated by the Late Bronze age eruption of Thera (Santorini), Greece. Pure Appl. Geophys. 2000, 157, 1227-1256. [CrossRef]

21. Maramai, A.; Brizuela, B.; Graziani, L. The euro-mediterranean tsunami catalogue. Ann. Geophys. 2014, 57, 4, s0435. [CrossRef]

22. Papazachos, B.C.; Papazachou, C. The Earthquakes of Greece; Ziti Publ. Co.: Thessaloniki, Greece, 2003.

23. Sørensen, M.B.; Spada, M.; Babeyko, A.; Wiemer, S.; Grünthal, G. Probabilistic tsunami hazard in the Mediterranean Sea. J. Geophys. Res. 2012, 117, 1-15. [CrossRef] 
24. Papadopoulos, G.A. Tsunami hazard in the Eastern Mediterranean: Strong earthquakes and tsunamis in the Corinth Gulf, Central Greece. Nat. Hazards 2003, 29, 437-464. [CrossRef]

25. Papadopoulos, G.A. Tsunamis in the East Mediterranean: A catalogue for the area of Greece and adjacent seas. In Proceedings of the International Workshop on Tsunami Risk Assessment beyond 2000, Moscow, Russia, 14-16 June 2000; pp. 34-42.

26. Hamouda, A.Z. Numerical computations of 1303 tsunamigenic propagation towards Alexandria, Egyptian Coast. J. African Earth Sci. 2006, 44, 37-44. [CrossRef]

27. Stiros, S.C. The AD 365 Crete earthquake and possible seismic clustering during the fourth to sixth centuries AD in the Eastern Mediterranean: A review of historical and archaeological data. J. Struct. Geol. 2001, 23, 545-562. [CrossRef]

28. Shaw, B.; Ambraseys, N.N.; England, P.C.; Floyd, M.A.; Gorman, G.J.; Higham, T.F.G.; Jackson, J.A.; Nocquet, J.M.; Pain, C.C.; Piggott, M.D. Eastern Mediterranean tectonics and tsunami hazard inferred from the AD 365 earthquake. Nat. Geosci. 2008, 1, 268-276. [CrossRef]

29. Werner, V.; Baika, K.; Tzigounaki, A.; Reicherter, K.; Papanikolaou, I.; Emde, K.; Fischer, P.; Vött, A. Mid-Holocene tectonic geomorphology of northern Crete deduced from a coastal sedimentary archive near Rethymnon and a Late Bronze Age Santorini tsunamite candidate. Geomorphology 2019, 326, 167-189. [CrossRef]

30. Dominey-Howes, D.; Dawson, A.; Smith, D. Late Holocene coastal tectonics at Falasarna, western Crete (Greece): A sedimentary contribution. In Coastal Tectonics; Special Publication, Stewart, I., Vita-Finzi, C., Eds.; Geological Society: London, UK, 1998; Volume 146, pp. 341-350. [CrossRef]

31. Ambraseys, N.N. The seismic sea wave of 9 July 1956, in the Greek Archipelago. J. Geophys. Res. 1960, 65, 1257-1265. [CrossRef]

32. Stiros, S.C.; Marangou, L.; Arnold, M. Quaternary uplift and tilting of Amorgos Island (southern Aegean) and the 1956 earthquake. Earth Planet. Sci. Lett. 1994, 128, 65-76. [CrossRef]

33. Dominey-Howes, D.T.M. Sedimentary deposits associated with the July 9 th 1956 Aegean Sea Tsunami. Phys. Chem. Earth 1996, 21, 51-55. [CrossRef]

34. Minoura, K.; Imamura, F.; Kuran, U.; Nakamura, T.; Papadopoulos, G.A.; Takahashi, T.; Yalciner, A.C. Discovery of Minoan tsunami deposits. Geology 2000, 28, 59-62. [CrossRef]

35. Dominey-Howes, D.T.M.; Papadopoulos, G.A.; Dawson, A.G. Geological and historical investigation of the 1650 Mt. Columbo (Thera Island) eruption and tsunami, Aegean Sea, Greece. Nat. Hazards 2000, 21, 83-96. [CrossRef]

36. Dall'Osso, F.; Dominey-Howes, D.; Tarbotton, C.; Summerhayes, S.; Withycombe, G. Revision and improvement of the PTVA-3 model for assessing tsunami building vulnerability using "international expert judgment”: Introducing the PTVA-4 model. Nat. Hazards 2016, 83, 1229-1256. [CrossRef]

37. Alexander, D. Confronting Catastrophe: New Perspectives on Natural Disasters; Oxford University Press: New York, NY, USA, 2000.

38. Iida, K. A relation of earthquake energy to tsunami energy and the estimation of the vertical displacement in a tsunami source. J. Earth Sci. 1963, 11, 49-67.

39. Bohnhoff, M.; Rische, M.; Meier, T.; Becker, D.; Stavrakakis, G.; Harjes, H.P. Microseismic activity in the Hellenic Volcanic Arc, Greece, with emphasis on the seismotectonic setting of the Santorini-Amorgos zone. Tectonophysics 2006, 423, 17-33. [CrossRef]

40. Dimitriadis, I.; Karagianni, E.; Panagiotopoulos, D.; Papazachos, C.; Hatzidimitriou, P.; Bohnhoff, M.; Rische, M.; Meier, T. Seismicity and active tectonics at Coloumbo Reef (Aegean Sea, Greece): Monitoring an active volcano at Santorini Volcanic Center using a temporary seismic network. Tectonophysics 2009, 465, 136-149. [CrossRef]

41. Fytikas, M.; Kolios, N.; Vougioukalakis, G. Post-Minoan volcanic activity of the Santorini volcano. Volcanic hazard and risk, forecasting possibilities, In Thera and the Aegean World III, Volume Two, Earth Sciences; Hardy, D.A., Keller, J., Galanopoulos, V.P., Flemming, N.C., Druitt, T.H., Eds.; The Thera Foundation: London, UK, 1990; pp. 183-198.

42. Bailey, J.C.; Jensen, E.S.; Hansen, A.; Kann, A.D.J.; Kann, K. Formation of heterogeneous magmatic series beneath North Santorini, South Aegean island arc. Lithos 2009, 110, 20-36. [CrossRef]

43. Sparks, R.S.J. The Santorini eruption and its consequences. Endeavour 1979, 3, 27-31. [CrossRef] 
44. Perissoratis, C. The Santorini volcanic complex and its relation to the stratigraphy and structure of the Aegean arc, Greece. Mar. Geol. 1995, 128, 37-58. [CrossRef]

45. Stiros, S.C. The 8.5+ magnitude, AD365 earthquake in Crete: Coastal uplift, topography changes, archaeological and historical signature. Quat. Int. 2010, 216, 54-63. [CrossRef]

46. ELSTAT (Hellenic Statistical Authority). 2011 Population-Housing Census; Hellenic Statistical Authority: Athens, Greece, 2014.

47. ELSTAT (Hellenic Statistical Authority). 2011 Buildings Census; Hellenic Statistical Authority: Athens, Greece, 2015.

48. Thywissen, K. Components of Risk: A Comparative Glossary; UNU-EHS: Bonn, Germany, 2006.

49. Odeh, D.J. Natural hazards vulnerability assessment for statewide mitigation planning in Rhode Island. Nat. Hazards Rev. 2002, 3, 177-187. [CrossRef]

50. Tanislav, D.; Costache, A.; Muratoreanu, G. Vulnerability to natural hazards in Romania. Forum Geogr. 2009, 8, 131-138.

51. Tragaki, A.; Gallousi, C.; Karymbalis, E. Coastal hazard vulnerability assessment based on geomorphic, oceanographic and demographic parameters: The case of the Peloponnese (southern Greece). Land 2018, 7, 56. [CrossRef]

52. Alberico, I.; Di Fiore, V.; Iavarone, R.; Petrosino, P.; Piemontese, L.; Tarallo, D.; Punzo, M.; Marsella, E. The tsunami vulnerability assessment of urban environments through freely available datasets: The case study of Napoli City (southern Italy). J. Mar. Sci. Eng. 2015, 3, 981-1005. [CrossRef]

53. Fritis, E.; Izquierdo, T.; Abad, M. Assessing the tsunami building vulnerability PTVA-3 and PTVA-4 models after the 16S 2015 event in the cities of Coquimbo-La Serena (Chile). Nat. Hazards Earth Syst. Sci. 2018, 18, 1703-1716. [CrossRef]

54. Harisuthan, S.; Hasalanka, H.; Kularatne, D.; Siriwardana, C. Applicability of the PTVA-4 model to evaluate the structural vulnerability of hospitals in Sri Lanka against tsunami. Int. J. Disaster Resil. Built Environ. 2020, 11, 581-596. [CrossRef]

55. Papathoma, M. Assessing Tsunami Vulnerability Using GIS with Special Reference to Greece. Ph.D. Thesis, Coventry University, Coventry, UK, 2003.

56. Dominey-Howes, D.; Papathoma, M. Validating a tsunami vulnerability assessment model (the PTVA model) using field data from the 2004 Indian Ocean tsunami. Nat. Hazards 2007, 40, 113-136. [CrossRef]

57. Dall'Osso, F.; Gonella, M.; Gabbianelli, G.; Withycombe, G.; Dominey-Howes, D. A revised (PTVA) model for assessing the vulnerability of buildings to tsunami damage. Nat. Hazards Earth Syst. Sci. 2009, 9, 1557-1565. [CrossRef]

58. Dall'Osso, F.; Gonella, M.; Gabbianelli, G.; Withycombe, G.; Dominey-Howes, D. Assessing the vulnerability of buildings to tsunami in Sydney. Nat. Hazards Earth Syst. Sci. 2009, 9, 2015-2026. [CrossRef]

59. Tarbotton, C.; Dall'Osso, F.; Dominey-Howes, D.; Goff, J. The use of empirical vulnerability functions to assess the response of buildings to tsunami impact: Comparative review and summary of best practice. Earth Sci. Rev. 2015, 142, 120-134. [CrossRef]

60. Bressan, L.; Guerrero, M.; Antonini, A.; Petruzzelli, V.; Archetti, R.; Lamberti, A.; Tinti, S. A laboratory experiment on the incipient motion of boulders by high-energy coastal flows. Earth Surf. Process Landf. 2018, 43, 2935-2947. [CrossRef]

Publisher's Note: MDPI stays neutral with regard to jurisdictional claims in published maps and institutional affiliations.

(C) 2020 by the authors. Licensee MDPI, Basel, Switzerland. This article is an open access article distributed under the terms and conditions of the Creative Commons Attribution (CC BY) license (http://creativecommons.org/licenses/by/4.0/). 